\title{
INTERPERSONAL MEANING ANALYSIS OF ADELE'S SONG LYRIC IN 21 ALBUM
}

\author{
Hernovianti Puspa Sari ${ }^{1}$, Neng Rini Dartini' ${ }^{2}$ Euis Rina Mulyani ${ }^{3}$ \\ ${ }^{1}$ IKIP Siliwangi \\ ${ }^{2}$ IKIP Siliwangi \\ ${ }^{3}$ IKIP Siliwangi \\ ${ }^{1}$ hernoviantipuspasarim@gmail.com, ${ }^{2}$ dartini.neng@gmail.com, ${ }^{3}$ mulyanieuisrina@ymail.com
}

\begin{abstract}
Songs are one of media in language to communicate or deliver a message which created by a songs' writer through a singer to listeners. Songs is very effective as a media in analyzing systemic functional linguistic, because in song contained two text at once, those are when a singers sing, the song is the spoken text, and the song lyric is the written text. The objective of this study is to describe the aspects of Interpersonal Meaning in the lyric of Adele's Album 21. The design of the research was descriptive qualitative method. The writers analyzed the a song entitled "Don't You Remember" based on the Subject, Finite, Predicator, Complement and Adjunct that describe in the table. The writers classified them based on Mood-Residue elements and made the conclusion based on the research findings. The results of the data analysis shows that the interpersonal meaning in the lyric Don't You Remember of Adele's album " 21 ", there are only 4 clauses which do not have aspects of interpersonal meaning from 28 clauses which be analyzed because the clauses only have one element, it is residue. Thus, the conclusion is $85.7 \%$ of the data can be analyzed to find out mood and residue as the aspects of interpersonal meaning.
\end{abstract}

Keywords: Interpersonal Meaning, Song lyric

\section{INTRODUCTION}

According to Hornby, 1987) in (Hariyanto, 2017)) language is a human and non-intensive methode of communicating ideas, feelings, and desires by means of a system of sounds and sounds symbols. In other word language is a media to receive and give messages among person by speaking or writing.

Songs are one of media in language to communicate or deliver a message which created by a songs' writer through a singer to listeners. Song is a part of literature (Siallagan, Manurung, \& Sinaga, 2017). Songs is very effective as a media in analyzing systemic functional linguistic, because in song contained two text at once, those are when a singers sing, the song is the spoken text, and the song lyric is the written text (Susanto \& Watik, 2017).

This study the writers focuses on the interpersonal relationship that can be seen through the interpersonal meaning realized on the Adele's song lyrics of " 21 " album and only focus on Don't You Remember song. The researchers conduct a linguistic reasearch on interpersonal meaning in communicating his/her song writer or singer emotion, feeling. desire, etc. In Systemic Functional Linguistic theory, how the wtiter or singer can exprecesses his/her idea, emotion, feeling, etc, can be seen through the use of interpersonal meaning. The objective of the study is to describe the Mood Element which is used in the lyrics of Adele's album 21. 


\section{Interpersonal Meaning}

Interpersonal meaning is a technical term in SFL related to someone's attitude and judgement (Firmansah, 2015). According to (Butt, 2011) in (Susanto \& Watik, 2017) interpersonal meaning is one of the most masic interactive distinction is between using language to exchange information and using it to exchange goods and services. The grammar of interpersonal meaning can be analysed using the Mood system, consisting of Mood and Residue.

\section{Analysis of Interpersonal Meaning}

\section{Analysis of Mood}

Mood is composed of funtional elements of subject and finite in which subject approves or disapproves argument whereas finite shows primary tense and aspect ((Halliday, 1985) in (Araghi \& Shayegh, 2011)). Mood system consists of two elemets, they are mood alement and residue. According to Firmansah, 2015) the main structure of mood are Subject and Finite. Subject is a past of verbal group. Finite can be representation of time speaking and the judgement of the speaker (Halliday \& Matthiessen, 2014).

2. Analysis of Residue

Residu is remainder of the clauses. It has sometimes been labelled 'Proposition'(Halliday \& Matthiessen, 2014). Residue consists of predicator, complement, and adjunct (Gerot \& Wignell, 1994). Mood and residue are the elements which set the clause as exchange. Those can be analyzed to set how interpersonal meaning is constructed in such situation (Firmansah, 2015).

\section{METHOD}

In this study, the writers analized interpersonal meaning and using descriptive qualitative research. According to (Creswell, 2009) in (Siallagan et al., 2017) a means for exploring and understanding the meaning individuals or groups ascribe to a social or human problem is called qualitative research. The writers searched the song of " 21 " album by Adele and only focus on Don't You Remember song. The writers analyzed the clauses of the song based on the Subject, Finite, Predicator, Complement and Adjunct. For the next step, the writers classified them based on Mood-Residue elements. To make the readers easy to understand, the writers analyzed the clause in form of the table. After that the writers classified the clause to get the most dominant of mood types. And the last steps, the writers made the conclusion based on the research findings.

\section{RESULTS AND DISCUSSION}

\section{Results}

Based on the procedure of analysing the data that has been mention above, it is got the result and discussion as follows.

When will I see you again?

Based on the analysis of the mood system, this clause has mood element and residu element.

Clause

Interpersonal Meaning Analysis

Mood Residue




\begin{tabular}{rrrrrr} 
& S & F & P & C & Aj \\
\hline When will I see you again? & When & Will & See & I & You again
\end{tabular}

Based on the data above, it shows that the clause ' when will I see you again' is formed by two element. The first is Mood and the second one is Residue. Mood in this clause consists of Subject (when) and finite (will), and element of Residue consists of Predicator (see), Compliment (I) and Adjunct (you again).

\section{You left with no goodbye}

\begin{tabular}{cccccc}
\multirow{2}{*}{ Clause } & \multicolumn{4}{c}{ Interpersonal Meaning Analysis } \\
\cline { 2 - 5 } & \multicolumn{4}{c}{ Mood } & \multicolumn{2}{c}{ Residue } \\
\cline { 2 - 5 } & S & F & P & C & Aj \\
\hline You left with no goodbye & You & left & & with no goodbye &
\end{tabular}

The table above shows that the clause 'You left with no goodbye' is formed by two element. They are Mood and Residue. Mood in this clause composed by Subject (you) and finite (left), and element of Residue consists of Compliment (with no goodbye).

Not a single word was said

Interpersonal Meaning Analysis

\begin{tabular}{ccccccc}
\cline { 2 - 6 } Clause & \multicolumn{3}{c}{ Mood } & \multicolumn{3}{c}{ Residue } \\
\cline { 2 - 6 } & $\mathrm{S}$ & $\mathrm{F}$ & $\mathrm{P}$ & $\mathrm{C}$ & $\mathrm{Aj}$ \\
\hline
\end{tabular}

Not a single word was said Not a single word was Said

Based on the data above, the clause 'Not a single word was said 'is formed by two element: Mood and Residue. The Mood consists of Subject (not a single word) and finite (was), while the element of Residue consists of Predicator (said).

No final kiss to seal any sins.

Interpersonal Meaning Analysis

\begin{tabular}{cccccc}
\cline { 2 - 5 } Clause & \multicolumn{3}{c}{ Mood } & \multicolumn{3}{c}{ Residue } \\
\cline { 2 - 5 } & $\mathrm{S}$ & $\mathrm{F}$ & $\mathrm{P}$ & $\mathrm{C}$ & $\mathrm{Aj}$ \\
\hline
\end{tabular}

Not final kiss to seal any $\quad$ Not final kiss $\quad$ to seal any sins

sins

The clause 'Not final kiss to seal any sins' is formed by two element, they are Mood and Residue. Mood in the clause is composed by Subject (not final kiss) and element of Residue composed by Predicator (to seal) and Complement (any sins). 
I had no idea of the state we were in.

\begin{tabular}{lllllll}
\multirow{2}{*}{ Clause } & \multicolumn{4}{c}{ Interpersonal Meaning Analysis } \\
\cline { 2 - 5 } & \multicolumn{4}{c}{ Mood } & \multicolumn{3}{c}{ Residue } \\
\cline { 2 - 5 } & $\mathrm{S}$ & $\mathrm{F}$ & $\mathrm{P}$ & $\mathrm{C}$ & $\mathrm{Aj}$ \\
\hline I had no idea of the state we were in & $\mathrm{I}$ & had & & no idea & of the state we were in
\end{tabular}

The table explains that the clause 'I had no idea of the state we were in' is composed by two element. The first is Mood and the last is Residue. The Mood consists of Subject (I) and Finite (had), and element of Residue consists of Complement (no idea) and Adjunct(of the state we were in).

I know I have a fickle heart and a bitterness

\begin{tabular}{llrccc}
\multirow{2}{*}{ Clause } & \multicolumn{5}{c}{ Interpersonal Meaning Analysis } \\
\cline { 2 - 6 } & \multicolumn{3}{c}{ Mood } & & \multicolumn{2}{c}{ Residue } \\
\cline { 2 - 5 } & $\mathrm{S}$ & $\mathrm{F}$ & $\mathrm{P}$ & $\mathrm{C}$ & $\mathrm{Aj}$ \\
\hline $\begin{array}{l}\text { I know I have a fickle } \\
\text { heart and a bitterness }\end{array}$ & $\mathrm{I}$ & know & Have & $\begin{array}{l}\text { a fickle heart and a } \\
\text { bitterness }\end{array}$ &
\end{tabular}

The clause 'I know I have a fickle heart and a bitterness' has two elements, they are Mood which consists of Subject (I) and Finite (know), and Residue which consists of Predicator (have) and Complement (a fickle heart and a bitterness).

And a wandering eye, and a heaviness in my head

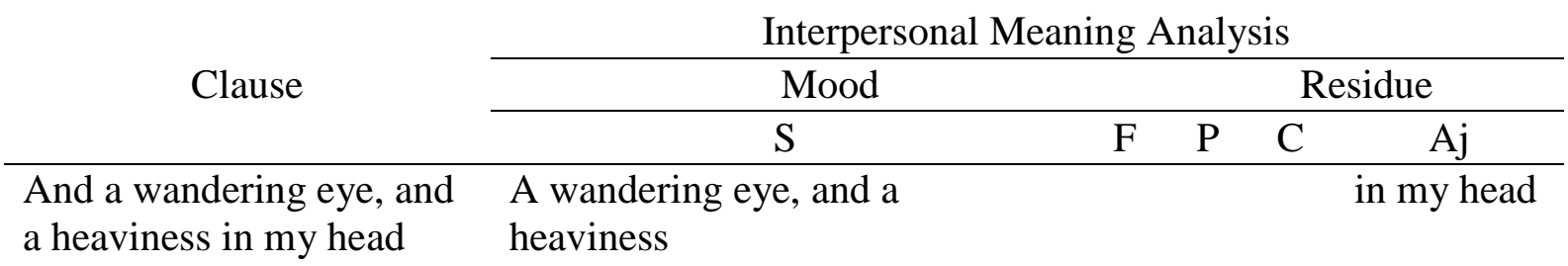

The clause 'And a wandering eye' and a heaviness in my head' is clause from the data above which formed by two element. The first is Mood which composed by Subject (wandering eye, and a heaviness) and the second one is Residue which composed by Adjunct (in my head).

But don't you remember

\begin{tabular}{ccccccc}
\multirow{2}{*}{ Clause } & \multicolumn{5}{c}{ Interpersonal Meaning Analysis } \\
\cline { 2 - 6 } & \multicolumn{4}{c}{ Mood } & Residue \\
\cline { 2 - 6 } & & S & F & P & C & $\mathrm{Aj}$ \\
\hline But don't you remember & You & & don't & & remember &
\end{tabular}


The data displays that the clause 'But don't you remember' has two elements: Mood and Residue. The Mood composed by Subject (you) and Finite (don't), while the element of Residue composed by Complement (remember).

The reason you loved me before

\begin{tabular}{cccccc}
\multirow{2}{*}{ Clause } & \multicolumn{4}{c}{ Interpersonal Meaning Analysis } \\
\cline { 2 - 5 } & \multicolumn{2}{c}{ Mood } & & Residue \\
\cline { 2 - 5 } & S & F & P & C & $\mathrm{Aj}$ \\
\hline The reason you loved me & the reason & & & you loved me before &
\end{tabular}
before

The data indicates that clause 'The reason you loved me before' has two elements. They are Mood and Residue. Mood of the clause consists of Subject (the) and the element of Residue consists of Complement (you loved me before).

Please remember me once more.

\begin{tabular}{llllll} 
& \multicolumn{5}{c}{ Interpersonal Meaning Analysis } \\
\cline { 2 - 5 } Clause & Mood & \multicolumn{4}{c}{ Residue } \\
\cline { 2 - 6 } & S F & P & C & $\mathrm{Aj}$ \\
\hline
\end{tabular}

Please remember me once more.

Please remember me once more.

The clause 'Please remember me once more' is formed by one element only, it is Residue which consists of Predicator (Please remember me once more).

When was the last time you thought of me?

\begin{tabular}{lccccc}
\multirow{2}{*}{\multicolumn{1}{c}{ Clause }} & \multicolumn{4}{c}{ Interpersonal Meaning Analysis } \\
\cline { 2 - 5 } & \multicolumn{2}{c}{ Mood } & \multicolumn{2}{c}{ Residue } \\
\cline { 2 - 5 } & when & was & P & C & Aj \\
\hline $\begin{array}{l}\text { When was the last time you } \\
\text { thought of me? }\end{array}$ & & & & $\begin{array}{l}\text { me } \\
\text { the }\end{array}$
\end{tabular}

The clause 'When was the last time you thought of me' is formed by two elements. The first is Mood which consist of Subject (when) and Finite (was), while the the second one is Residue which consists of Complement (you thought of me) and Adjunct (the last time).

Or have you completely erased me from your memory?

\begin{tabular}{lccccc}
\multirow{2}{*}{\multicolumn{1}{c}{ Clause }} & \multicolumn{4}{c}{ Interpersonal Meaning Analysis } \\
\cline { 2 - 6 } & \multicolumn{3}{c}{ Mood } & & Residue \\
\cline { 2 - 5 } & S & F & P & C & Aj \\
\hline $\begin{array}{l}\text { Or have you completely erased me } \\
\text { from your memory? }\end{array}$ & you & have & & & $\begin{array}{l}\text { Completely erased me } \\
\text { from your memory }\end{array}$
\end{tabular}

The clause 'Or have you completely erased me from your memory?' is composed by two elements, they are Mood which composed by Subject (you) and Finite (have) and the element of Residue composed by Adjunct (completely erased me from your memory). 
I often think about where I went wrong

\begin{tabular}{llllll}
\multirow{2}{*}{ Clause } & \multicolumn{4}{c}{ Interpersonal Meaning Analysis } \\
\cline { 2 - 6 } & \multicolumn{2}{c}{ Mood } & \multicolumn{3}{c}{ Residue } \\
\cline { 2 - 5 } & $\mathrm{S}$ & $\mathrm{F}$ & $\mathrm{P}$ & $\mathrm{C}$ & $\mathrm{Aj}$ \\
\hline $\begin{array}{l}\text { I often think about where I went } \\
\text { wrong }\end{array}$ & $\mathrm{I}$ & & often & think about & where I went \\
wrong
\end{tabular}

The clause 'I often think about where I went wrong' is formed by two elements: Mood and Residue. The Mood consists of Subject (I) and the element of Residue consists of Predicator (often), Complement (think about), and Adjunct (where I went wrong).

The more I do

\begin{tabular}{|c|c|c|c|c|c|}
\hline \multirow{3}{*}{ Clause } & \multicolumn{5}{|c|}{ Interpersonal Meaning Analysis } \\
\hline & \multicolumn{2}{|c|}{ Mood } & \multicolumn{3}{|c|}{ Residue } \\
\hline & $\mathrm{S}$ & $\mathrm{F}$ & $\mathrm{P}$ & $\mathrm{C}$ & $\mathrm{Aj}$ \\
\hline
\end{tabular}

Based on the data above, it displays that the clause 'The more I do' has two elements. They are Mood and Residue. Mood in the clause composed by Subject (I) and Finite (do), while the element of Residue composed by Complement (the more).

The less I know

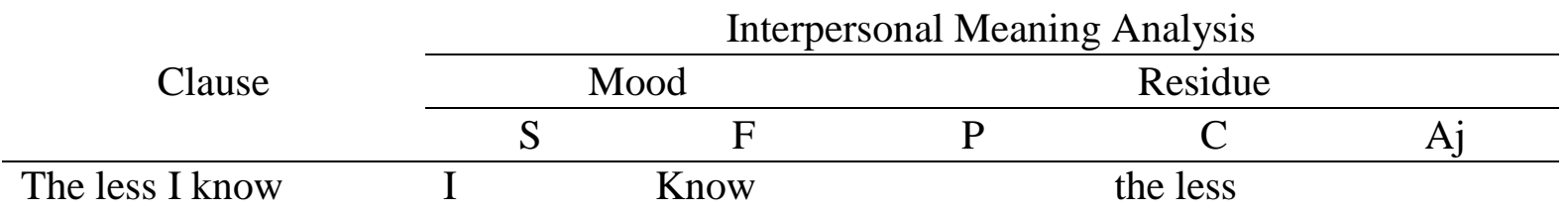

'The less I know' is the clause from the table above which formed by two elements. The first is Mood that composed by Subject (I) and Finite (know) and the last is Residue that composed by Complement (the less).

But I know I have a fickle heart and a bitterness

\begin{tabular}{llllllr}
\multirow{2}{*}{ Clause } & \multicolumn{5}{c}{ Interpersonal Meaning Analysis } \\
\cline { 2 - 6 } & \multicolumn{3}{c}{ Mood } & Residue & $\mathrm{Aj}$ \\
\cline { 2 - 6 } & $\mathrm{S}$ & $\mathrm{F}$ & $\mathrm{P}$ & $\mathrm{C}$ & \\
\hline $\begin{array}{l}\text { I know I have a fickle heart and } \\
\text { a bitterness }\end{array}$ & I & Kno & have & a fickle heart and a bitterness & \\
& & W & & &
\end{tabular}

The clause 'I know I have a fickle heart and a bitterness' has two elements of interpersonal meaning, they are Mood which consists of Subject (I) and Finite (know) and the second one is Residue which consists of Predicator (have) and Complement (a fickle heart and a bitterness).

And a wandering eye, and a heaviness in my head

\begin{tabular}{cccccc} 
& \multicolumn{4}{c}{ Interpersonal Meaning Analysis } \\
\cline { 2 - 6 } Clause & \multicolumn{3}{c}{ Mood } & \multicolumn{4}{c}{ Residue } \\
\cline { 2 - 6 }
\end{tabular}


And a wandering eye, and a A wandering eye, and a heaviness

in my heaviness in my head

head

The clause 'And a wandering eye' and a heaviness in my head' is formed by two elements, they are Mood and Residue. The Mood in this clause consists of Subject (wandering eye, and a heaviness), while the element of Residue consists of Adjunct (in my head).

\section{Gave you the space so you could breathe}

\begin{tabular}{lccccc}
\multirow{3}{*}{ Clause } & \multicolumn{4}{c}{ Interpersonal Meaning Analysis } \\
\cline { 2 - 5 } & \multicolumn{3}{c}{ Mood } & \multicolumn{3}{c}{ Residue } \\
\cline { 2 - 6 } & S & F & P & C & Aj \\
\hline Gave you the space so you could & You & gave & & the space & so you could breathe
\end{tabular}
breathe

The clause 'Gave you the space so you could breathe' is formed by two elements, they are Mood and Residue. Mood in the clause consists of Subject (you) and Finite (gave), whilst the element of Residue of the clause consists of Complement (the space) and Adjunct (so you could breathe).

I kept my distance so you would be free

\begin{tabular}{llllll}
\multirow{2}{*}{ Clause } & \multicolumn{4}{c}{ Interpersonal Meaning Analysis } \\
\cline { 2 - 5 } & \multicolumn{2}{c}{ Mood } & \multicolumn{3}{c}{ Residue } \\
\cline { 2 - 5 } & $\mathrm{S}$ & $\mathrm{F}$ & $\mathrm{P}$ & $\mathrm{C}$ & $\mathrm{Aj}$ \\
\hline $\begin{array}{l}\text { I kept my distance so you would be } \\
\text { free }\end{array}$ & $\mathrm{I}$ & $\mathrm{kept}$ & & my distance & $\begin{array}{l}\text { so you would be } \\
\text { free }\end{array}$
\end{tabular}

Based on the data above, it displays that the clause 'I kept my distance so you would be free' is consistof two element. The first is Mood which composed by Subject (I) and Finite (kept) and the second one is Residue which consists of Complement (my distance) and Adjunct (so you would be free).

And hoped that you'd find the missing piece

\begin{tabular}{|c|c|c|c|c|c|}
\hline \multirow{3}{*}{ Clause } & \multicolumn{5}{|c|}{ Interpersonal Meaning Analysis } \\
\hline & \multicolumn{2}{|c|}{ Mood } & \multicolumn{3}{|c|}{ Residue } \\
\hline & $\mathrm{S}$ & $\mathrm{F}$ & $\mathrm{P}$ & $\mathrm{C}$ & $\begin{array}{c}\text { A } \\
\text { i }\end{array}$ \\
\hline And hoped that you find the missing piece & $\begin{array}{l}\text { That } \\
\text { you }\end{array}$ & $\begin{array}{l}\text { hope } \\
\text { d }\end{array}$ & find & i & \\
\hline
\end{tabular}

Based on the data above, it shows that the clause 'And hoped that you find the missing piece' is formed by two elements. The first is Mood that composed by Subject (that you) and Finite (hoped), the second one is Residue which consists of Predicator (find) and Complement (the missing piece). 
To bring you back to me

Interpersonal Meaning Analysis

\begin{tabular}{lllllll}
\cline { 2 - 5 } Clause & \multicolumn{4}{c}{ Mood } & & \multicolumn{2}{c}{ Residue } \\
\cline { 2 - 6 } & S & F & P & C & Aj \\
\hline
\end{tabular}

To bring you back to me

to bring

you back to me

Based on the data above, it shows that the clause 'To bring you back to me' is formed only one element, it is Residue element, which consists of Predicator (to bring) and Complement (you back to me).

\section{CONCLUSION}

Based on the result of the data analysis of Interpersonal Meaning in the lyrics Don't You Remember on Adele's album "21", there are only four clauses which do not have aspects of interpersonal meaning from twenty eight clauses that be analyzed.The four clauses are only have one element, it is residue. It can be conclude that $85.7 \%$ of the data is able to analyse to find out mood and residue as the aspects of interpersonal meaning.

\section{ACKNOWLEDGMENTS}

Alhamdulillahi Robbil 'Alamin, first of all the reseachers would like to express her highest gratitude to Allah SWT for blessing and mercy to complete this journal. The researchers presents her sincere thanks go to Euis Rina Mulyani, S.Pd, .M.Pd as our jurnal superfisor for her kind support and IKIP Siliwangi for the express permission to run the major phares of the study.

\section{REFERENCES}

Araghi, S. M., \& Shayegh, K. (2011). Interpersonal Metafunction of Gender Talk in ELT Classrooms, 1(July), 25-32. Retrieved from www.academians.org

Butt, D. (2011). Using Functional Grammar (Revised Ed). Sydney: Macquarie University Press.

Creswell, J. . (2009). Research Design: Qualitative, quantitative and mixed method approches (thrid edit). USA: Sage Publications, Inc.

Firmansah, A. (2015). Interpersonal Meaning in Netanyahu'S Speech. English Review: Journal of English Education, 4(1), 1-8. Retrieved from https://journal.uniku.ac.id/index.php/ERJEE

Gerot, L., \& Wignell, P. (1994). Making Sense of Functional Grammar (first edit). Australia: Gerd Stabler.

Halliday, M. A. . (1985). An Introduction to Functional Grammar. Edward Arnold.

Halliday, M. A. ., \& Matthiessen, M. I. . (2014). Halliday's introduction to functional grammar (Fourth edi). USA and Canada: Routledge. https://doi.org/10.4324/9780203431269

Hariyanto. (2017). The Analysis of Figurative Language Used in the Lyric of Firework by Katy Perry ( A Study of Semantic ), 10(1), 46-60. Retrieved from https://ejournal.radenintan.ac.id/index.php/engedu

Hornby, A. . (1987). Oxford Advanced Learners Dictionary. Oxford: Oxford University Press Inc.

Siallagan, S. R., Manurung, S., \& Sinaga, J. B. (2017). Analysis of Figurative Language and 
Imagery in Taylor Swift' s Songs, VIII(1), 55-67.

Susanto, D. A., \& Watik, S. (2017). The Interpersonal Meaning Realized in The Lyrics of Christina Perri's Album “Love Strong” and The Contribution for Teaching, 09(03), 283291. 